\title{
Arlenelepis harpiprioni gen. et sp. n. (Cestoda: Dilepididae) from Harpiprion caerulescens (Vieillot) (Aves: Threskiornithidae) in Paraguay
}

\author{
Boyko B. Georgiev ${ }^{1,2}$ and Claude Vaucher $^{3}$ \\ ${ }^{1}$ Central Laboratory of General Ecology, Bulgarian Academy of Sciences, 2 Gagarin Street, 1113 Sofia, Bulgaria; \\ ${ }^{2}$ Present address: Department of Zoology, The Natural History Museum, Cromwell Road, London SW7 5BD, UK; \\ ${ }^{3}$ Natural History Museum, P.O. Box 6434, 1211 Geneva 6, Switzerland
}

Key words: Cestoda, Arlenelepis harpiprioni gen. et sp. n., Dilepididae, Harpiprion caerulescens, Paraguay

\begin{abstract}
Arlenelepis harpiprioni gen. et sp. n. (Cyclophyllidea, Dilepididae) is described from the plumbeous ibis Harpiprion caerulescens (Vieillot) (Ciconiiformes, Threskiornithidae) in Province Concepción, Paraguay. This cestode is characterised by a very small body (not exceeding $5 \mathrm{~mm}$ in length) consisting of about 30 proglottides, musculo-glandular rostellar apparatus, rostellar hooks arranged in two regular rows, few testes (7-10 in number) situated mostly in a post-ovarian group but one testis pre-ovarian, a large oval cirrus sac reaching antiporal osmoregulatory canals, massive cirrus armed with needle-shaped and thorn-shaped spines, long convoluted vagina, and longitudinally elongate sacciform horseshoe-shaped uterus with deep lobes of the medial uterine wall. The new genus is unique among the family Dilepididae in possessing a rhynchus armed with conical spines.
\end{abstract}

The species composition of the Dilepididae parasitizing threskiornithid birds (ibises and spoonbills) in the Neotropical Region is poorly known. According to Bona (1975), the previous records of dilepidid cestodes from hosts belonging to this family in this region are as follows: Cyclustera capito (Rudolphi, 1819) from Platalea ajaja Linnaeus in Brazil, Mexico and Cuba and from Eudocimus albus (Linnaeus) from Cuba; Cyclustera ibisae (Schmidt et Bush, 1972) from Eudocimus albus in Cuba; Ascodilepis transfuga (Krabbe, 1869) from P. ajaja in Brazil; Dilepis bicoronata Fuhrmann, 1908 from Mesembrinibis cayennensis (Gmelin) in Brazil; and Eugonodaeum nasutum (Fuhrmann, 1908) from Theristicus caudatus (Boddaert) in Brazil (the nomenclature is according to Bona 1994). Recently, Chimaerula bonai Georgiev et Vaucher, 2000, a parasite of Phimosus infuscatus (Lichtenstein) in Paraguay, was added to this list (Georgiev and Vaucher 2000).

The aim of the present article is to describe a new dilepidid cestode collected from the plumbeous ibis, Harpiprion caerulescens (Vieillot), during a survey on avian cestodes in Paraguay.

\section{MATERIALS AND METHODS}

A single specimen of Harpiprion caerulescens was examined for helminth parasites in Paraguay by an expedition of the Natural History Museum, Geneva (field collection number of the host specimen PY 6559). The intestine was opened longitudinally, placed in water for few minutes and fixed in hot $4 \%$ neutral formalin. In laboratory, the cestodes were removed under stereomicroscope, washed in water and stored in $70 \%$ ethanol. They were stained in Mayer's hydrochloric carmine or iron acetocarmine, dehydrated in ethanol series, cleared in eugenol and mounted in Canada balsam. One scolex was mounted in Berlese's medium. The type specimens were deposited in the Invertebrate Collection of the Natural History Museum, Geneva (MHNG) and in the Helminthological Collection of the Institute of Parasitology, Academy of Sciences of the Czech Republic, České Budějovice (IPCAS). The host specimen is deposited in the Ornithological Collection of MHNG, no. 1720.086 .

The measurements of the testes, vas deferens, cirrus sac, vitellarium, ovary, vagina and seminal receptacle are taken from fully developed mature proglottides only. The metrical and meristic data are presented as the range, with the mean and the number of measurements or counts (n) in parentheses. The measurements are given in $\mu \mathrm{m}$ unless otherwise stated. The terms used for the developmental stages of proglottides are as previously described (Georgiev and Vaucher 2001). The categories used for defining the body length, the number of the rostellar hooks and the number of the testes in the generic diagnosis are as adopted by Bona (1994). The nomenclature of birds follows Wolters (1982).

\section{RESULTS}

\section{Arlenelepis gen. n.}

Diagnosis. Body very small. Scolex with conically protruded anterior part, forming evaginable long rhynchus armed with spines. Rostellar apparatus musculoglandular. Rostellum powerful. Rostellar sac thickwalled, oval to pyriform. Rostellar hooks numerous, situated in two regular rows, posteriorly directed when 
rostellum retracted. Proglottides craspedote. Genital pores far anterior, irregularly alternating. Genital atrium thick-walled, surrounded by compact cellular masses. Genital ducts between osmoregulatory canals. Testes few, mostly in posterior half of median field but one testis anterior to antiporal wing of ovary; antiporal testes may overlap antiporal wing of ovary. External vas deferens forming numerous coils dorsal to cirrus sac and few coils anterior and antiporal to it. Cirrus sac large, oblique, oval, thick-walled. Cirrus massive, when withdrawn highly convoluted, armed mostly with needleshaped spines, only its basal portion armed with thornshaped spines. Vitellarium median, slightly lobed or compact. Ovary two-winged, symmetrical, slightly lobed or compact. Seminal receptacle very small. Vagina opening dorsally to orifice of cirrus sac, long, convoluted; its copulatory part consisting of thickwalled canal and thick cellular sleeve, provided with powerful sphincter. Uterus in pregravid proglottides sacciform, longitudinally elongate, horseshoe-shaped, its lateral parts forming deep lobes on medial uterine wall. Ripe eggs unknown. In Threskiornithidae, South America. Type and only species: Arlenelepis harpiprioni $\mathrm{sp} . \mathrm{n}$.

E t y m o 1 o g y : The new genus is named after Dr. Arlene Jones, The Natural History Museum, London, in recognition of her contribution to the cestode systematics.

\section{Arlenelepis harpiprioni $\mathrm{sp} . \mathrm{n}$.}

Figs. 1-9

Description. Body very small, ribbon-shaped. Entire pregravid specimen $4.03 \mathrm{~mm}$ long, consisting of 27 proglottides: 10 juvenile, 10 premature, 6 mature and 1 pregravid (Fig. 1). Another specimen (terminating proglottis mature) $4.64 \mathrm{~mm}$ long, consisting of 32 proglottides. Maximum width of strobila at mature proglottides, 250 $313(297, \mathrm{n}=5)$. No postmature proglottides found in material studied, i.e., development from mature to pregravid proglottides rapid.

Scolex outlined from neck by its greatest width, with maximum diameter at level of suckers, 112-124 (118, n =5); anterior part of scolex conically protruded (Fig. 2). Rostellar apparatus musculo-glandular. Rostellum highly muscular, containing thick longitudinal muscular fibres and few glandular cells; circular fibres not observed. Measurements of rostellum varying in large range: $63 \times$ $52,72 \times 61,75 \times 68,104 \times 54,141 \times 47$; anterior tegument of rostellum thick, forming dome-shaped pad. Rostellar sac thick-walled, oval to pyriform, 127-191 $\times$ 70-84 (155 × 76, $\mathrm{n}=5)$; well-developed glandular masses situated within rostellar sac between rostellum and rostellar sac walls. Anterior to rostellar sac, evaginable cylindrical rhyncheal canal presents; its tegument thick, provided with conical spines 4-5 long (Fig. 2). Compact aggregation of glandular tissue situated just posterior to rostellar sac. Rostellar hooks $16(n=6)$ in number, situated in two regular rows (Fig. 3). Anterior and posterior hooks with different shape (Figs. 4, 5).
Anterior hooks 29-30 ( $\mathrm{n}=4)$ long, length of blade 1011. Posterior hooks 27-28 $(n=4)$ long; length of blade $7-8$. Suckers round, $39-63(55, \mathrm{n}=20)$ in diameter, with well-developed musculature. Neck 55-90 long, 43-80 wide at narrowest part.

Ventral osmoregulatory canals 5-9 $(\mathrm{n}=10)$ wide, with transverse anastomosis along posterior margin of each proglottis. Dorsal osmoregulatory canals $2-5(\mathrm{n}=$ 10) wide.

Proglottides craspedote, with rounded lateral margins. Mature proglottides from almost as long as wide to twice longer than wide (Figs. 1, 6). Pregravid proglottides twice or more longer than wide, measuring 505$620 \times 273-298$ (Fig. 7). Genital pores far anterior in both mature and pregravid proglottides, situated at anterior $20 \%$ of length of lateral proglottis margin (Figs. $6,7)$; irregularly alternating, predominantly in short series (mostly one or two but up to four proglottides in a unilateral series). No genital papilla observed. Genital atrium thick-walled, tubular, its base slightly expanded; surrounded by compact masses of intensely stained cells (Figs. 6-9). Genital ducts between osmoregulatory canals.

Testes $7-10(n=62)$, mostly $8(n=26)$ or $9(n=27)$, usually in single layer, mostly in posterior half of median field but one testis anterior to antiporal wing of ovary, at some distance from remaining testes (Fig. 6). In some proglottides, antiporal testes dorsally overlapping antiporal wing of ovary and then forming entire asymmetrical testicular field. Diameter of fully developed testes $48-75(63, n=20)$. Vestigial testes dorsal to uterus in pregravid proglottides (Fig. 7). External vas deferens convoluted, with diameter 8-16 $(12, \mathrm{n}=10)$, forming numerous coils situated mostly dorsally to cirrus sac; few coils anterior and antiporal to cirrus sac. Prostate cells surrounding small portion of external vas deferens near cirrus sac. Cirrus sac oblique, oval, thickwalled, massive, reaching antiporal osmoregulatory canals or sometimes slightly crossing them, 141-210 $\times$ 64-89 $(175 \times 74, n=20)$. Internal vas deferens forming few coils in antiporal half of cirrus sac. Withdrawn cirrus massive, highly convoluted (Fig. 8). Basal part of cirrus provided with needle-shaped spines with length 3 ; size of spines increasing and they gradually pass into thorn-shaped spines with length 7-10, which gradually pass into dense needle-shaped spines with length 7-8. Total length of withdrawn cirrus about 500-600. Evaginated cirrus not seen. Intensely stained cells situated within cirrus sac, surrounding distal part of withdrawn cirrus.

Vitellarium median, oval or with irregular shape near to oval, slightly lobed or compact, 41-63 $(50, \mathrm{n}=10)$ wide. Ovary two-winged, symmetrical (wings of almost equal size), 106-189 $(160, \mathrm{n}=10)$ wide, slightly lobed or compact; wings connected by narrow isthmus situated in anterior part of organ. Mehlis' gland not distinct. Seminal receptacle (sometimes not distinct) very small, 

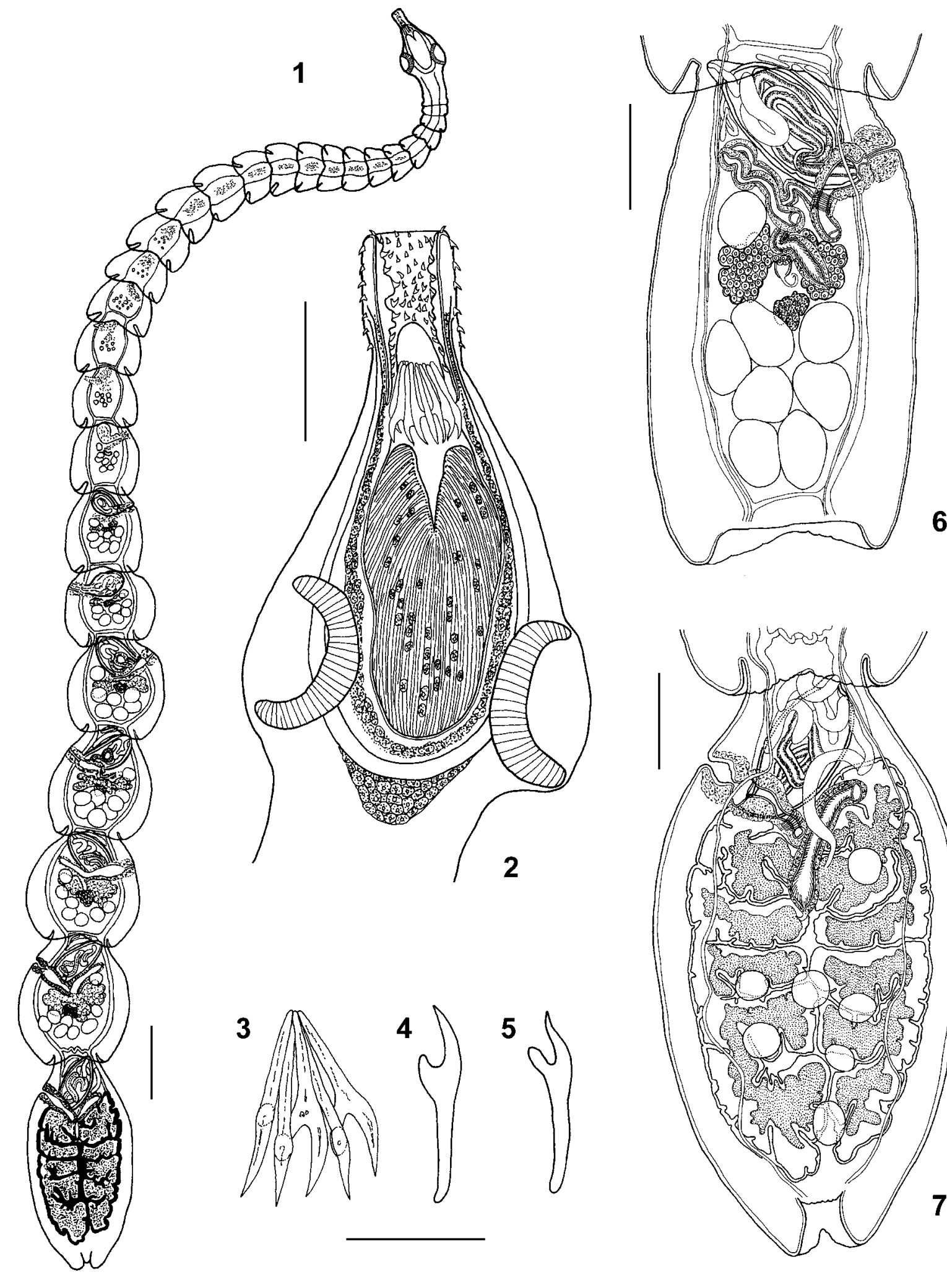

6

Figs. 1-7. Arlenelepis harpiprioni gen. et sp. n. Fig. 1. Entire view, holotype. Fig. 2. Scolex. Fig. 3. Crown of rostellar hooks (detail) demonstrating the arrangement in two regular rows. Fig. 4. Anterior rostellar hook. Fig. 5. Posterior rostellar hook. Fig. 6. Mature proglottis, dorsal view. Fig. 7. Pregravid proglottis, dorsal view. Scale bars: Fig. $1=200 \mu \mathrm{m}$; Fig. $2=50 \mu \mathrm{m}$; Figs. $3-5=20 \mu \mathrm{m}$; Figs. $6,7=100 \mu \mathrm{m}$. 


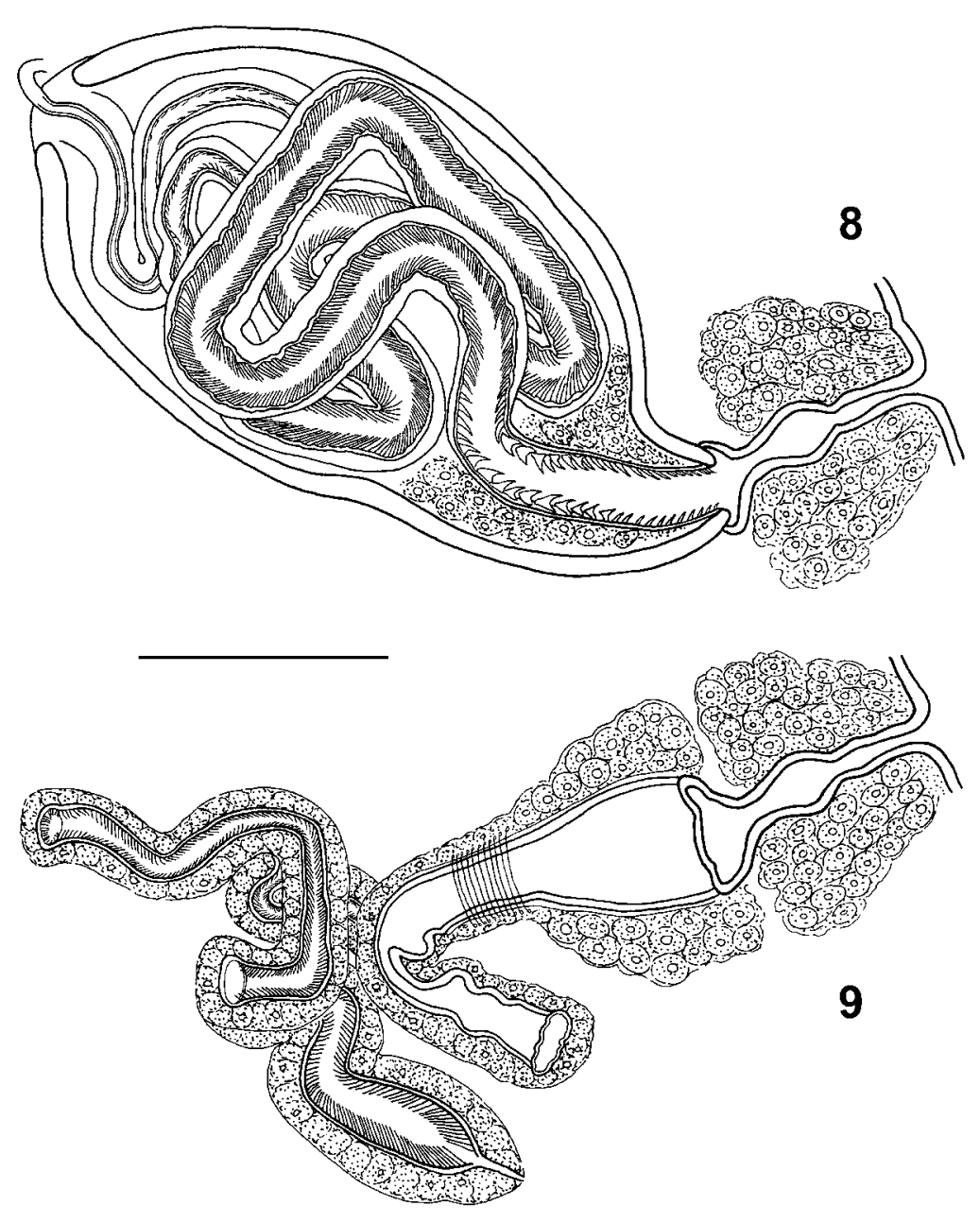

Figs. 8, 9. Arlenelepis harpiprioni gen. et sp. n. Fig. 8. Cirrus sac. Fig. 9. Vagina. Scale bar $=50 \mu \mathrm{m}$.

oval, $18-27 \times 11-15(22 \times 13, \mathrm{n}=5)$, just anterior to vitellarium. Vagina opening dorsally to orifice of cirrus sac and following convoluted course, reaching to antiporal osmoregulatory canals and then turning into postero-poral direction (Fig. 9). Distal portion of copulatory part of vagina infundibular, surrounded by thick cellular sleeve; diameter of infundibular portion (together with cellular sleeve) $45-60(52, \mathrm{n}=10)$; separated from proximal portion by powerful sphincter. Proximal portion long, convoluted, cylindrical, with diameter (together with cellular sleeve) 22-30 $(25, \mathrm{n}=10)$. Vaginal canal thick-walled, lined by long microtriches. Conductive part of vagina thin, rather short, cylindrical, curved.

Uterus in pregravid proglottides sacciform, occupying almost entire median field, horseshoe-shaped and longitudinally elongate, divided by deep longitudinal septum into two lateral parts. This septum connected with secondary septa, almost perpendicular to main septum, thus forming deep lobes of medial uterine wall (Fig. 7). Fully developed eggs not available.
T y p e h o s t: Harpiprion caerulescens (Vieillot) (Ciconiiformes, Threskiornithidae).

M a te ria $1 \mathrm{st} \mathrm{udied:} 6$ specimens and fragments of a few additional specimens ( 9 slides).

H o 1 o t y p e : MHNG 35001 INVE, on the same slide with three paratype specimens.

P a r a t y p e s : MHNG 35002 INVE; IPCAS C-379, 1 specimen and 1 fragment ( 2 slides).

T y p e 1 o c a 1 i t y : The mouth of Río Aquidaban, Province Concepción, Paraguay.

D a t e : 15 October 1988.

$S$ i t e : Small intestines.

E t y m o log y: The new species is named after the generic name of the host.

\section{DISCUSSION}

For the purposes of this study, we prefer to consider the Dilepididae in the concept presented in the last entire revision of the family (Bona 1994), i.e., including the Gryporhynchidae Spasskii et Spasskaya, 1973. Our 
preference is based on the lack of a clear differential diagnosis of the latter taxon. In addition, there is not an explicit concept about the generic composition of the Gryporhynchidae. We accept as sound the opinion of Scholz and Salgado-Maldonado (2001) and Scholz et al. (2002), who preferred to consider the "gryporhynchid" genera within the Dilepididae "until the taxonomy of this group of cyclophyllidean tapeworms is resolved" (Scholz and Salgado-Maldonado 2001).

Until present, species of the genera Cyclorchida Fuhrmann, 1907, Cyclustera Fuhrmann, 1901, Paradilepis Hsü, 1935, Ascodilepis Guildal, 1960, Dilepis Weinland, 1858, Eugonodaeum Beddard, 1913 (= Nasutaenia Baer et Bona, 1960) and Chimaerula Bona, 1994 have been reported from birds of the family Threskiornithidae (Matevosyan 1963, Bona 1975, 1994, Ryzhikov et al. 1985, Georgiev and Vaucher 2000). Because some doubts about the identification of the host of the type species (see Bona 1978), the genus Clelandia Johnston, 1909 may also be considered as a possible parasite of threskiornithids.

Most of the genera mentioned are characterised by particular patterns of rostellar apparatus, termed by Bona (1994) "cyclusteroid" (for Cyclustera, Paradilepis and Ascodilepis) and "parvitaenioid" (for Cyclorchida, Clelandia and some other genera); see also Pichelin et al. (1998) for a definition of the parvitaenioid rostellar apparatus. The main characters shared between the cyclusteroid and parvitaenioid pattern of rostellar apparatus include: (1) the invaginable anterior part of the rostellum, (2) the anterior direction of the blades of the rostellar hooks when the rostellum is retracted, and (3) the complete or the almost complete absence of glandular tissue associated with the rostellar apparatus (Bona 1994, Pichelin et al. 1998). Arlenelepis is characterised by a musculo-glandular rostellar apparatus, with a dome-shaped anterior tegumental pad of the rostellum, with blades of rostellar hooks directed posteriorly when the rostellum is retracted, and with well-developed glandular masses in the rostellar sac. By these peculiarities, the new genus can be distinguished from genera possessing parvitaenioid or cyclusteroid pattern of the rostellar apparatus.

Arlenelepis can be distinguished from Eugonodaeum and Dilepis, both having unilateral genital pores (Bona 1994), by its irregularly alternating genital pores.

Arlenelepis harpiprioni has some similarities with species of the genus Chimaerula (for characteristics, see
Bona 1994, Vasileva et al. 1998, Georgiev and Vaucher 2000), including such details as the presence of one preovarian testis and the long convoluted vagina provided with a sphincter. However, Chimaerula spp. have only four testes per proglottis as a rule, while the number of the testes of $A$. harpiprioni is $7-10$. There is a substantial difference in the cirrus armament: the presence of a terminal bundle of long delicate bristles in Chimaerula spp. and its absence in A. harpiprioni.

Arlenelepis is unique among the genera of the family Dilepididae relative to the presence of conical spines on the rhynchus. We mark as a rhynchus the invaginable canal in the scolex apex, which forms the external wall of the rostellar apparatus when the rostellum is protruded. The presence of armament on the rhynchus is a frequent character in the family Amabiliidae (e.g., Gulyaev 1990, Vasileva et al. 2003). It also occurs in the hymenolepidid genera Echinorhynchotaenia Fuhrmann, 1909 and Vigisolepis Matevosyan, 1945 (see Czaplinski and Vaucher 1994). In the course of the present study, we checked the position of the additional spines in these two hymenolepidid genera on the basis of specimens from MHNG. We found that these spines are situated on the rhynchus, as it is in Arlenelepis, and not on the rostellum.

Another unique character of Arlenelepis is the horseshoe-shaped uterus with a particular outline. Its two lateral parts, divided from one another by a deep posterior septum, are characterised by medial walls forming deep lobes. Similar structure of the uterus is not known in the Dilepididae. However, it can be considered as a derived condition of the horseshoe-shaped uterus with irregular lobes described in Chimaerula woodlandi (Prudhoe, 1960) Bona, 1994, the type species of Chimaerula (see Bona 1994).

On the basis of aforementioned, we consider the cestode species described as a member of a new genus belonging to the family Dilepididae.

Acknowledgements. We are grateful to the Ministry of Agriculture and Livestock of Paraguay for providing facilities during the fieldwork and the members of the expedition for collecting specimens described (C. Dlouhy, F. Baud, T. Jaccoud and C. Wyler). J. Mariaux and P. Nikolov kindly commented on the draft of the present article. This study was supported by the Natural History Museum (Geneva) and the Bulgarian Academy of Sciences.

\section{REFERENCES}

BONA F.V. 1975: Étude critique et taxonomique des Dilepididae Fuhrm., 1907 (Cestoda) parasites des Ciconii-formes. Considérations sur la spécificité et la spéciation. Mon. Zool. Ital., Monografia 1, xii +750 pp.

BONA F.V. 1978: The genus Clelandia Johnston, 1909 and its affinities with Parvitaenia and Neogryporhynchus (Ces- toda, Dilepididae). Ann. Parasitol. Hum. Comp. 53: 163180.

BONA F.V. 1994: Family Dilepididae Railliet \& Henry, 1909. In: L.F. Khalil, A. Jones and R.A. Bray (Eds.), Keys to the Cestode Parasites of Vertebrates. CAB International, Wallingford, pp. 443-554. 
CZAPLINSKI B., VAUCHER C. 1994: Family Hymenolepididae Ariola, 1899. In: L.F. Khalil, A. Jones and R.A. Bray (Eds.), Keys to the Cestode Parasites of Vertebrates. CAB International, Wallingford, pp. 595663.

GEORGIEV B.B., VAUCHER C. 2000: Chimaerula bonai sp. n. (Cestoda: Dilepididae) from bare-faced ibis, Phimosus infuscatus (Lichtenstein) (Aves: Threskiornithidae) in Paraguay. Folia Parasitol. 47: 303-308.

GEORGIEV B.B., VAUCHER C. 2001: Revision of the genus Parvirostrum Fuhrmann, 1908 (Cestoda, Cyclophyllidea, Paruterinidae). Syst. Parasitol. 50: 13-29.

GULYAEV V.D. 1990: On the morphology and taxonomy of the genus Tatria (s. 1.) (Cestoda, Schistotaeniinae) from grebes in West Siberia and Trans-Urals. In: G.S. Zolotarenko (Ed.), Redkie Gel'minty, Kleshchi i Nasekomye. Nauka, Novosibirsk, pp. 4-18. (In Russian.)

MATEVOSYAN E.M. 1963: [Dilepidoidea - Tapeworms of Domesticated and Wild Animals.] In: K.I. Skryabin (Ed.), Osnovy Tsestodologii, Vol. 3. Izdatel'stvo Akademii Nauk SSSR, Moscow, 688 pp. (In Russian.)

PICHELIN S., CRIBB T.H., BONA F.V. 1998: Glossocercus chelodinae (MacCallum, 1921) n. comb. (Cestoda: Dilepididae) from freshwater turtles in Australia and a redefinition of the genus Bancroftiella Johnston, 1911. Syst. Parasitol. 39: 165-181.
RYZHIKOV K.M., RYŠAVÝ B., KHOKHLOVA I.G., TOLKACHEVA L.M., KORNYUSHIN V.V. 1985: Helminths of the Fish-eating Birds of the Palaearctic Region. Vol. II. Cestoda and Acanthocephales. Academia, Prague, 411 pp.

SCHOLZ T., KUCHTA R., SALGADO-MALDONADO G. 2002: Cestodes of the family Dilepididae (Cestoda: Cyclophyllidea) from fish-eating birds in Mexico: a survey of species. Syst. Parasitol. 52: 171-182.

SCHOLZ T., SALGADO-MALDONADO G. 2001: Metacestodes of the family Dilepididae (Cestoda: Cyclophyllidea) parasitising fishes in Mexico. Syst. Parasitol. 49: 23-40.

VASILEVA G.P., GEORGIEV B.B., GENOV T. 1998: Redescription of Chimaerula leonovi (Belogurov \& Zueva, 1968) n. comb. (Cestoda, Dilepididae). Syst. Parasitol. 40: 229-235.

VASILEVA G.P., GIBSON D.I., BRAY R.A. 2003: Taxonomic revision of the genus Tatria Kowalewski, 1904 (Cestoda: Amabiliidae): redescriptions of $T$. biremis Kowalewski, 1904, T. minor Kowalewski, 1904 and the description of T. gulyaevi n. sp. from Palaearctic grebes. Syst. Parasitol. 54: 177-198.

WOLTERS H.E. 1982: Die Vogelarten der Erde. Paul Parey Verlag, Hamburg, 745 pp.

Accepted 3 September 2004 